\title{
Pengetahuan Ibu tentang Imunisasi terhadap Kesehatan Balita di Desa Sumput Kecamatan Driyorejo Kabupaten Gresik
}

\author{
Retno Oktavianingsih ${ }^{(1)}$, Wara Pramesti ${ }^{(2)}$ \\ (1), (2) Universitas PGRI Adi Buana Surabaya \\ Jl. Dukuh Menanggal XII Telp. (031) 8289873 Surabaya 60234 \\ Email: Retno.oktavianingsih93@gmail.com \\ Estipra72@gmail.com
}

\begin{abstract}
ABSTRAK
Imunisasi Sebagai salah satu upaya preventif untuk mencegah penyakit melalui pemberian kekebalan tubuh harus dilaksanakan secara terus menerus ,menyeluruh,dan dilaksanakan sesuai standar sehingga mampu memberikan perlindungan kesehatan dan memutus mata rantai penularan. Dengan 62 reponden ibu-ibu untuk mengetahui pendidikan ibu, pekerjaan ibu, umur ibu dan pengetahuan ibu tentang imunisasi.Berdasarkan analisis uji Hormes and Lemeshow persamaan regresi logistik biner bisa dipakai untuk menganalisis Pengetahuan Ibu tentang Imunisasi terhadap Kesehatan Balita $(Y)$. Hal ini diketahui karena nilai sig $>0,05$. Dari hasil anaisis regresi diatas tidak dihasilkan persamaan regresi, interpretasi dari analisisbisa dilihat dalam bab pembahasan interprestasi model. Berdasarkan hasil uji Wald diketahui variabel bebas tidak berpengaruh secara signifikan terhadap variabel terikat. Berdasarkan koefesien determinasi Nagelkerke sebesar 0,148 atau sebesar 14,8\%. Hal ini berarti Pengetahuan ibu tentang imunisasi tidak mempengaruhi kesehatan balita secara umum. Tidak ada hubungan antara pendidikan ibu, pekerjaan ibu, umur ibu, dan pengetahuan ibu tentang imunisasi terhadap variabel kesehatan balita karena setinggi apapun pendidikan ibu, pekerjaan ibu, umur ibu, dan pengetahuan ibu tapi apabila balita tidak diperhatikan dengan sungguh-sungguh tentu akan mempengaruhi kesehatan balita.
\end{abstract}

Kata Kunci : imunisasi, kesehatan balita, and regresi logistic biner

\begin{abstract}
Immunization As one of the preventive efforts to prevent the disease through immunity should be carried out continuously, thoroughly, and implemented according to standards as provide health protection and break the chain of transmission. With 62 respondents mothers to know maternal education, mother's job, mother's age and mother's knowledge about immunization. Based on test analysis of Hormer and Lemeshow binary logistic regression equation can be used to analyze mother's knowledge about health immunization (Y). This is known because the sig value> 0.05 . From the result of regression anaisis above is not generated by regression equation, interpretation from analysis seen in discussion chapter of model interpretation. Based on the Wald test results known independent variables do not significantly affect the dependent variable. Based on Nagelkerke determination coefficient of 0,148 or $14,8 \%$. This means that mother's knowledge about immunization does not affect toddler health in general. There is no relationship between maternal education, mother's job, mother's age, and mother's knowledge about immunization against the health variable toddler because of the height of any mother's education, mother's job, mother's age, and mother's knowledge but if the toddler is not paid attention seriously will affect health Toddler.
\end{abstract}

Keywords : Immunization, infant health, and binary logistic regression

\section{PENDAHULUAN}

Pada dasarnya imunisasi itu sebagai upaya pencegahan yang utama dalam mencapai kesejahteraan anak,senantiasa berubah sesuai dengan perubahan epidemiologi dan pengadaan vaksin yang semakin lengkap.Untuk itu diperlukan pelaksanaan imunisasi secara menyeluruh. Dalam rangka Universal Children Immunization ( UCI ) 
,Indonesia telah memenuhi kebutuhan anak - anak yaitu pemberian vaksin DTP/Hipatitis B,IPV,BCG,Campak dan lain sebagainya.

Pelaksanaan kegiatan vaksinasi ditetapkan secara nasional pada tahun 1973 kemudian pada bulan April tahun 1974 Indonesia resmi dinyatakan bebas cacar oleh WHO.Program pemberian vaksinasi tersebut diatas tidak hanya dilakukan sekali saja namun berkelanjutan dengan waktu yang sudah ditentu hingga anak Indonesia bebas dari penyakit

Pada penelitian ini menggunakan data primer yaitu melalui kuesioner yang dilakukan di Desa Sumput Kecamatan Driyorejo Kabupaten Gresik.dengan menggunakan metode analisis regresi logistic ordinal.

\section{Tinjauan Pustaka}

\subsection{Tinjauan Non Statistika}

\subsubsection{Pengertian imunisasi}

Menurut Pendapat Katt ( 1999 ) mengatakan bahwa Imunisasi adalah:

Sumbangan ilmu pengetahuan yang terbaik yang pernah diberikan para Ilmuwan didunia ini.

\subsection{2 jenis-jenis vaksin dalam imunisasi}

Vaksin BCG ( Baesillus Calmette Guerin ), vaksin DPT, vaksin TT, vaksin DT, vaksin polio, vaksin campak, vaksin hepatitis $B$, dan vaksin varisela.

\subsubsection{Tanda-tanda Balita Sehat}

- Anak terlihat lincah dan Aktif

- Bahagia dan responsif

- Rambut tidak mudah kusam dan rontok

- Gigi Cemerlang

- Gusi merah muda

- Kulit bersih

- Kuku Merah Muda

- Suhu tubuh antara $36,5^{\circ} \mathrm{C}-37,5^{\circ} \mathrm{C}$

- Makan Lahap

\subsubsection{Tanda-tanda Balita yang Tidak Sehat}

- Demam

- Dehidrasi / Kekurangan ion dalam tubuh

- Muntah

- $\quad$ Sulit Bernafas

- Pusar dan penis berwarna merah atau berdarah

- Ruam /Bercak merah

- Pilek

\subsection{Pengertian Pengetahuan Ibu tentang Imunisasi}

Menurut Pendapat "Soejono Soekamto" dalam bukunya Sosiologi dijelaskan bahwa :Pengertian pengetahuan adalah : Pengetahuan yang dapat disusun secara sistematis dengan menggunakan kekuatan akal pikiran .Pengetahuan akan selalu dapat diperiksa dan diuji dengan kritis oleh setiap orang yang memiliki niat mengetahuinya. Menurut Pendapat “V.Afayanev
" dalam bukunya Marxist Philosophy adalah: Sesuatu pengetahuan manusia tentang alam ,masyarakat dan Pikiran

\subsection{Tinjauan Statistika}

\subsubsection{Umur}

Istilah usia diartikan dengan lamanya keberadaan seseorang diukur dalam satuan waktu di pandang dari segi kronologik, individu normal yang memperlihatkan derajat perkembangan anatomis dan fisiologik sama (Nuswantari, 1998). Usia adalah lama waktu hidup atau ada (sejak dilahirkan atau diadakan) (Hoetomo, 2005). Umur yaitu usia individu yang terhitung mulai saat dilahirkan sampai saat berulang tahun. Semakin cukup umur maka tingkat kematangan dan kekuatan seseorang akan lebih matang dalam berpikir dan bekerja (Arini H, 2012).

\subsubsection{Pekerjaan}

Pekerjaan adalah studi sistematis mengenai tugas, kewajiban, dan tanggung jawab dari suatu pekerjaan, serta pengetahuan, kemampuan, dan keahlian yang dibutuhkan untuk mengerjakan pekerjaan tersebut. Analisis pekerjaan adalah titik awal untuk hampir semua fungsi personalia dan analisis ini sangat penting untuk mengembangkan cara penilaian personalia (Wheaton \& Whetzel, 1997).

\subsubsection{Pendidikan}

Menurut Driyarkara (1950) Pendidikan diartikan sebagai suatu upaya dalam memanusiakan manusia muda atau pengangkatan manusia muda ke taraf yang insani. Menurut Stella van Petten Henderson bahwa Pendidikan yaitu suatu kombinasai dari pertumbuhan dan perkembangan insani dengan warisan sosial.

Berdasarkan definisi diatas dapat disimpulkan pendidikan adalah upaya dalam pembentukan serta perkembangan pola pikir dan karakter.

\subsection{Tinjauan Statistika}

\subsubsection{Uji Independensi}

Uji independensi digunakan untuk mengetahui kebebasan antara variabel prediktor dengan variabel respon. Menurut Agresti (2007), dalam tabel kontingensi dua arah dengan probabilitas gabungan untuk dua variabel respon hipotesisnya dinyatakan sebagai berikut:

$\mathrm{H}_{0}: \pi_{i j}=\pi_{i+} \pi_{+j}$ (tidak ada hubungan antara variabel prediktor dan variabel respon atau independen)

$\mathrm{H}_{1}: \pi_{i j} \neq \pi_{i+} \pi_{+j}$ (ada hubungan antara variabel prediktor dan variabel respon atau dependen) 
Untuk uji independen dalam tabel kontingensi $\boldsymbol{i} \times \boldsymbol{j}$ digunakan statistik uji Pearson $\left(\chi^{2}\right)$ dan Likelihood-Ratio Test ( $G^{2}$ ).

$\chi^{2}=\sum \frac{\left(n_{i j}-\hat{\mu}_{i j}\right)^{2}}{\hat{\mu}_{i j}}$ dan $G^{2}=2 \sum n_{i j} \log \left(\frac{n_{i j}}{\hat{\mu}_{i j}}\right)$

dimana $\hat{\mu}_{i j}=$ estimasi nilai harapan, $\hat{\mu}_{i j}=n p_{i+} p_{+j}=n\left(\frac{n_{i+}}{n}\right)\left(\frac{n_{+j}}{n}\right)=\frac{n_{i+} n_{+j}}{n}$

Pengambilan keputusan didasarkan pada tolak $\mathrm{H}_{0}$ apabila Statistik uji $\chi_{\text {hitung }}^{2}$ atau $G_{\text {hitung }}^{2}>\chi_{\text {tabel }}^{2}$ dengan $d f=(i-1)(j-1)$.

\subsection{Regresi Logistik Biner}

Regresi logistik biner adalah suatu analisis data yang digunakan untuk mencari hubungan antara variabel respon $(\mathrm{Y})$ yang bersifat biner dengan variabel prediktor $(\mathrm{X})$. Variabel respon $(\mathrm{Y})$ terdiri dari 2 kategori yaitu sukses dan gagal yang dinotasikan dengan $\mathrm{Y}=1$ (sukses) dan $\mathrm{Y}=0$ (gagal). Dalam keadaan demikian, variabel respon (Y) mengikuti distribusi bernoulli untuk setiap observasi tunggal. Fungsi probabilitas untuk setiap observasi adalah sebagai berikut (Hosmer dan Lemeshow, 2000) :

$f\left(Y_{i}, \pi_{i}\right)=\pi_{i}^{Y_{i}}\left(1-\pi_{i}\right)^{1-Y_{i}} ; Y=0,1$

Dimana jika $Y=0$ maka $f(Y)=1-\pi$ dan $Y=1$ maka $f(Y)=\pi$. Fungsi regresi logistiknya dapat dituliskan sebagai berikut :

$f(z)=\frac{e^{z}}{1+e^{z}}$

A. Uji Signifikansi Parameter

Pengujian Parameter Model Regresi Logistik Pengujian parameter digunakan untuk mengetahui apakah variabel prediktor yang terdapat dalam model yang diperoleh berpengaruh secara signifikan terhadap variabel respon. Pengujian parameter terdiri dari uji individu dan uji serentak.

\section{B. Uji Parsial}

Hasil pengujian secara individu akan menunjukkan apakah suatu variabel prediktor layak untuk masuk dalam model atau tidak.

$>$ Hipotesis :

$$
\begin{aligned}
& H_{0}: \beta_{j}=0 \\
& H_{1}: \beta_{j} \neq 0, \text { dengan } \mathrm{j}=1,2, \ldots, \mathrm{p}
\end{aligned}
$$

$>$ Statistik uji :

Uji Wald

$$
W=\frac{\hat{\beta}_{j}}{S E\left(\hat{\beta}_{j}\right)}
$$

$>$ Daerah penolakan $H_{0}$ adalah jika $|\boldsymbol{W}|>\boldsymbol{Z}_{\alpha / 2} \quad$ atau $|W|^{2}>\chi_{(v, \alpha)}^{2}$ dengan derajat bebas $v$.

\section{Uji Serentak}

Uji serentak dilakukan untuk mengetahui signifikansi parameter $\beta$ terhadap variabel respon secara keseluruhan. Pengujian signifikansi parameter tersebut menggunakan statistik uji G. Dimana statisrik uji G mengikuti distribusi Chi-Square.

$>$ Hipotesis :

$$
H_{0}: \beta_{1}=\beta_{2}=\ldots=\beta_{J}=0
$$

$H_{1}$ :minimal ada satu $\beta_{J} \neq 0$, dengan $\mathrm{j}=1,2, \ldots, \mathrm{p}$

$>$ Statistik uji :

$$
G=-2 \ln \frac{\left(\frac{n_{1}}{n}\right)^{n_{1}}\left(\frac{n_{0}}{n}\right)^{n_{0}}}{\sum_{i=1}^{n} \hat{\pi}_{i}^{Y_{i}}\left(1-\hat{\pi}_{i}\right)^{\left(1-Y_{i}\right)}}
$$

$>$ Daerah penolakan $H_{0}$ adalah jika $G>\chi_{(V, \alpha)}^{2}$ atau p_value $<\alpha$.

\section{Uji Kesesuaian Model}

Uji kesesuaian model digunakan untuk menilai apakah model sesuai atau tidak. Pada uji ini, statistik uji yang digunakan adalah Hosmer dan Lemeshow, 2000.

$>$ Hipotesis :

$H_{0}$ :model sesuai (tidak ada perbedaan antara hasil observasi dengan hasil prediksi)

$H_{1}$ :model tidak sesuai (ada perbedaan antara hasil observasi dengan hasil prediksi)

Statistik uji :

$$
\chi^{2}=\sum_{k=1}^{g} \frac{\left(O_{k}-n_{k}{ }_{k} \bar{\pi}_{k}\right)^{2}}{n_{k}{ }_{k} \bar{\pi}_{k}\left(1-\bar{\pi}_{k}\right)}
$$

dengan:

$O_{k}=\sum_{j=1}^{n_{k}^{\prime}} y_{j} \quad \begin{aligned} & \text { jumlah variabel respon pada group } \\ & \text { ke-k }\end{aligned}$ $\bar{\pi}_{k}=\sum_{j=1}^{n_{k}^{\prime}} \frac{m_{j} \hat{\pi}_{j}}{n_{k}^{\prime}} \quad$ rata-rata taksiran probabilitas banyaknya observasi yang memiliki nilai $m_{j}=\hat{\pi}_{j}$

$n^{\prime}{ }_{j}=$ Banyaknya observasi pada group ke-k

Pengambilan keputusan didasarkan pada tolak $\mathrm{H}_{0}$ jika $x_{\text {hitung }}^{2}>x_{(\alpha, d b)}^{2}$ dengan $d b=\mathrm{g}-2$. Statistik uji yang digunakan 
adalah statistik uji Chi-square (Hosmer dan Lemeshow, 2000).

E. Interpretasi Koefisien Parameter

Interpretasi koefisien parameter dari suatu model inferensi dan pengambilan kesimpulan berdasarkan pada koefisien parameter. Koefisien menggambarkan perubahan pada variabel respon perunit untuk setiap perubahan variabel prediktor. Interpretasi koefisien parameter ini menyangkut dua hal, yaitu :

1. Perkiraan mengenai hubungan fungsional antara variabel respon dengan variabel prediktor.

2. Menentukan pengaruh dari setiap unit perubahan variabel prediktor terhadap variabel respon.

Tabel 2.1 Nilai Error untuk Respon Biner

\begin{tabular}{|c|c|c|}
\hline & $\mathrm{X}=1$ & $\mathrm{X}=0$ \\
\hline $\mathrm{Y}=1$ & $\pi(1)=\frac{e^{\beta_{0}+\beta_{1}}}{1+e^{\beta_{0}+\beta_{1}}}$ & $\pi(0)=\frac{e^{\beta_{0}}}{1+e^{\beta_{0}}}$ \\
\hline $\mathrm{Y}=0$ & $1-\pi(1)=\frac{1}{1+e^{\beta_{0}+\beta_{1}}}$ & $1-\pi(0)=\frac{1}{1+e^{\beta_{0}}}$ \\
\hline
\end{tabular}

Odds ratio dituliskan sebagai berikut :

Sehingga $\theta=\exp \left(\hat{\beta}_{j}\right)$ dan $\ln \theta=\left(\hat{\beta}_{j}\right)$

\section{Metodologi Penilitian}

\subsection{Populasi}

Keseluruhan subjek penelitian yang dijadikan sebagai objek peneliti .Atau dapat diartikan wilayah generasi yang terdiri atas objek dan subjek yang berkualitas dan karakter tertentu yang ditetapkan oleh Peneliti untuk dipelajari kemudian ditarik kesimpulan ( Sugiono ,2005 ).

\subsection{Sampel}

Maksudnya adalah sebagian dari subjek dalam populasi yang diteliti sudah tentu mampu secara represetatif dapat digunakan atau mewakili populasinya ( Sabar ,2007 )

\subsection{Variabel dan Definisi Operasional}

Definisi Operasional Variabel yaitu menggambarkan atau mendiskripsikan penelitian sedemikian rupa sehingga variabel tersebut bersifat spesifik (Tidak berinterpretasiganda ) dan terukur (Observable / measurable ).Dari penjelasan diatas serta berdasarkan hasil penelitian yang penulis dapatkan dilapangan bahwa variabel bebasnya dalam penulisan skripsi ini adalah pengetahuan ibu tentang imunisasi dan variabel terikatnya adalah kesehatan balita.

\subsection{Metode Pengumpulan Data dan Instrumen}

Agar supaya dapat terealisasi sesuai dengan tujuan yang diharapkan oleh penulis dalam penulisan skripsi atau karya ilmiah ini,maka penulis menggunakan metode pengumpulan data yang disebut dengan istilah kuesioner ( Pemberian angket ) pada responden.

\section{Hasil dan Pembahasan}

\subsection{Uji Validitas}

Hipotesis yang akan diuji adalah :Ho : Tidak adanya korelasi antar pertanyaan kuisioner (rhitung $<$ rtabel $)$

$H_{1}$ : Adanya korelasi antar pertanyaan kuisioner $\left(r_{\text {hitung }}>r_{\text {tabel }}\right)$

Tabel 4.1 Uji Validitas ke-1

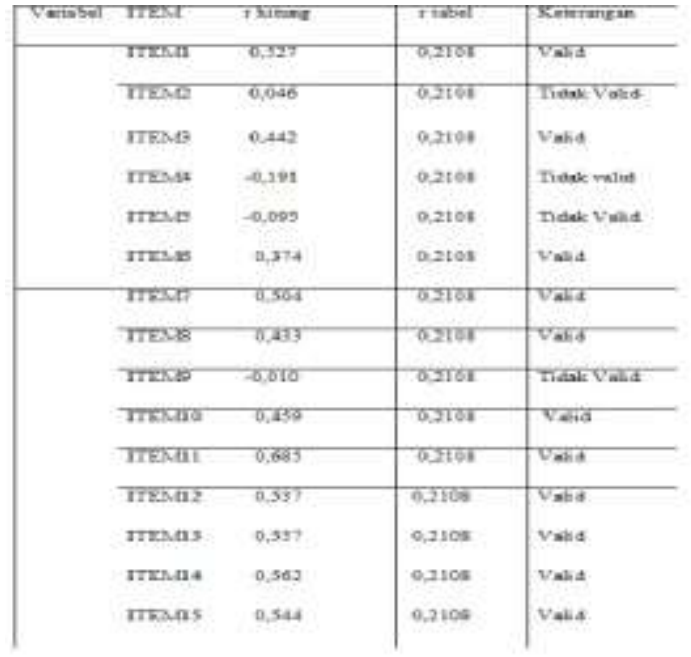

Di uji ke 1 akan memberikan informasi data yang tidak valid akan di buang pada uji yang ke 2 Yaitu ITEM2, ITEM4,ITEM5, dan ITEM9 Uji Validitas ke 2

Tabel 4.2 Uji Validitas ke-2

\begin{tabular}{|c|c|c|c|c|}
\hline $\begin{array}{c}\text { Varia } \\
\text { bel }\end{array}$ & ITEM & r hitung & r tabel & Keterangan \\
\hline & ITEM1 & 0,527 & 0,2108 & Valid \\
\hline & ITEM3 & 0,442 & 0,2108 & Valid \\
\hline & ITEM6 & 0,374 & 0,2108 & Valid \\
\hline & ITEM7 & 0,504 & 0,2108 & Valid \\
\hline & ITEM8 & 0,433 & 0,2108 & Valid \\
\hline & ITEM10 & 0,459 & 0,2108 & Valid \\
\hline & ITEM11 & 0,685 & 0,2108 & Valid \\
\hline & ITEM12 & 0,537 & 0,2108 & Valid \\
\hline & ITEM13 & 0,557 & 0,2108 & Valid \\
\hline & ITEM14 & 0,562 & 0,2108 & Valid \\
\hline & ITEM15 & 0,544 & 0,2108 & Valid \\
\hline
\end{tabular}

Kesimpulan dari uji validitas adalah bahwa ada keterkaitan pada setiap kuisioner.

\subsubsection{Uji Reliabilitas}

Tabel 4.3 Uji Realibilitas

\begin{tabular}{|l|l|}
\hline Cronbach's Alpha & N of Items \\
\hline 0,830 & 11 \\
\hline \multicolumn{1}{|c|}{ Berdasarkan hasil perhitungan uji } \\
reliabilitas didapat nilai cronbach"s alpha
\end{tabular}

kuisioner adalah 0,830. Nilai ini lebih besar dari 
standar minimal agar kuisioner dapat dijadikan sebagai alat ukur yaitu 0,6. Keputusan yang diambil adalah tolak $H_{0}$ dan terima $H_{l}$.

\subsection{Uji Independensi}

Uji independensi digunakan untuk mengetahui kebebasan antara variabel prediktor dengan variabel respon. Tolak $\mathrm{H}_{0}$ jika $G_{\text {hitung }}^{2}$ atau $\chi_{\text {hitung }}^{2}>\chi_{\text {tabel }}^{2}$ atau jika nilai Sig. $<\alpha(0,05)$ dengan hipotesis sebagai berikut:

$\mathrm{H}_{0}$ : tidak ada hubungan antara variabel prediktor dengan variabel respon.

$\mathrm{H}_{1}$ : ada hubungan antara variabel prediktor dengan variabel respon.

\begin{tabular}{|c|c|c|c|c|c|}
\hline $\begin{array}{l}\text { Variabel } \\
\text { Proldacuar }\end{array}$ & $\begin{array}{l}\text { Merten } \\
\text { Caissemere }\end{array}$ & $\Delta d$ & 50 & Ko whin: & Kentinewhon \\
\hline Anderition the & DEe & $y$ & otes & Tancis & 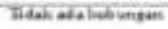 \\
\hline Dheodean an & 2,039 & 1 & 0.082 & Daves $\mathrm{H}_{4}$ & Tadurada huationgan \\
\hline Utwar the & 17,093 & i6 & 036 & Danims 而, & 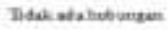 \\
\hline 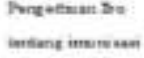 & 12,640 & 14 & 0.39 & Trums $\mathrm{H}_{\text {, }}$ & Th tak ata huhungan \\
\hline
\end{tabular}

\subsubsection{Pemodelan Regresi Logistik Biner secara} Individu

Pemodelan regresi logistik biner secara individu digunakan untuk mengetahui signifikansi masing-masing parameter dengan menggunakan Uji Wald dan untuk mengetahui variabel mana saja yang layak masuk ke dalam model. Dengan hipotesis sebagai berikut:

$\mathrm{H}_{0}: \beta_{j k}=0$; (tidak ada pengaruh antara variabel prediktor ke-j dengan variabel respon).

$\mathrm{H}_{1}: \beta_{j k} \neq 0 \quad$ (ada pengaruh antara variabel prediktor ke-j dengan variabel respon).

dimana: $j=1,2, \ldots, p$

Tolah $\mathrm{H}_{0}$ jika nilai $W_{\text {hitung }}^{2}($ Wald $)>\chi_{\text {tabel }}^{2}$ atau nilai Sig. $<\alpha$.

\section{Pendidikan Ibu $\left(\mathbf{X}_{1}\right)$ dengan Kesehatan} Balita (Y)

Berdasarkan Tabel 4.5 dapat diketahui bahwa tidak terdapat nilai yang signifikan, sehingga dapat disimpulkan variabel pendidikan ibu tidak dapat dibentuk model logit dari hasil analisis diatas.

Tabel 4.5 Estimasi Parameter Pendidikan Ibu

\begin{tabular}{|c|c|c|c|c|c|c|}
\hline \multicolumn{7}{|c|}{ dengan Kesehatan Balita } \\
\hline & I & S.E & Wob & II & sis. & Ep(a) \\
\hline Fendidiks ibu & & & वक्ता & $\bar{I}$ & 0,002 & \\
\hline Pandiatikm abu(1) & 21,201 & $28 a 00,72$ & $a, 000$ & $\mathrm{t}$ & 0,959 & I61547 ates at \\
\hline Fendetion abias & $0,28 \mathrm{~s}$ & 1.439 & a.8? & 1 & 0,84y & 1,320 \\
\hline Comutart & 0,000 & 1.426 & $q \infty 0$ & 3 & 1000 & 1,000 \\
\hline
\end{tabular}

2. Pekerjaan Ibu $\left(X_{2}\right)$ dengan Kesehatan Balita (Y)

$$
\text { Berdasarkan Tabel } 4.10 \text { dapat }
$$
diketahui bahwa nilai signifikansi dari kesehatan balita dengan pekerjaan ibu yaitu sebesar $0,095>$ alpha $(0,05)$ sehingga disimpulkan tidak layak masuk ke dalam model.

Tabel 4.6 Estimasi Parameter Pekerjaan ibu dengan Kesehatan Balita

\begin{tabular}{|c|c|c|c|c|c|c|}
\hline & I & If. & Wad & th & sit. & Exal3 \\
\hline Feiariaan bu(1) & 0,86 & 0,527 & 2790 & 1 & 0,05 & 2,413 \\
\hline Conmant & 0.243 & Q.379 & Q 343 & 1 & 0,05 & 9367 \\
\hline
\end{tabular}

3. Umur Ibu ( $\left.X_{3}\right)$ dengan Kesehatan Balita (Y) Berdasarkan Tabel 4.7 dapat diketahui bahwa nilai signifikansi dari kesehatan balita dengan pekerjaan ibu yaitu sebesar 0,843 > alpha $(0,05)$ sehingga disimpulkan tidak layak masuk ke dalam model.

Tabel 4.7 Estimasi Parameter Umur Ibu dengan

\begin{tabular}{|c|c|c|c|c|c|c|}
\hline \multicolumn{7}{|c|}{ Kesehatan Balita } \\
\hline & (6) & 38 & Wat & at & fig & fopd \\
\hline Ijmot is. & 0,010 & 0, Bail & 0.039 & 1 & Ras 3 & 0,900 \\
\hline Constare & 0,613 & 1.475 & 0,173 & 1 & $\mathrm{~B}, 7 \mathrm{~T}$ & 1.845 \\
\hline
\end{tabular}

4. Pengetahuan Ibu tentang Imunisasi ( $\left.\mathrm{X}_{\mathbf{4}}\right)$ dengan Kesehatan Balita (Y)

Berdasarkan Tabel 4.8 dapat diketahui bahwa nilai signifikansi dari kesehatan balita dengan pekerjaan ibu yaitu sebesar 0,209 > alpha $(0,05)$ sehingga disimpulkan tidak layak masuk ke dalam model.

Tabel 4.8 Estimasi Parameter Pengetahuan Ibu tentang Imunisasi dengan Kesehatan Balita

\begin{tabular}{|c|c|c|c|c|c|c|}
\hline \\
\hline & 8 & IF. & Wate & z & Sis & Explat \\
\hline Fengratum bu & Q⿻肀二丿 & 0047 & 1576 & 1 & Q200 & 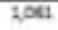 \\
\hline Contars & $-2,523$ & 2276 & 1.221 & 1 & Q.2क & Qवल \\
\hline
\end{tabular}

\subsubsection{Pemodelan Regresi Logistik Biner secara Serentak}

Pengujian regresi logistik biner ini dilakukan antara variabel prediktor (X) dengan variabel respon kesehatan balita (Y). Pada uji regresi logistik biner secara serentak ini dilihat dari variabel-variabel yang signifikan menggunakan analisis regresi logistik biner secara individu. Tetapi di penujian sebelumnya tidak ada variabel bebas yang signifikan maka akan diadakan pengujian regresi logistik biner secara serentak ini tanpa melihat variabel-variabel yang signifikan atau tidak, dilakukan dengan hipotesis sebagai berikut:

$\mathrm{H}_{0}: \beta_{2 k}=\beta_{3 k}=\beta_{4 k}=0$ (tidak ada pengaruh antara variabel prediktor dengan variabel respon).

$\mathrm{H}_{1}$ : minimal satu $\beta_{j k} \neq 0$ (minimal ada satu variabel prediktor berpengaruh terhadap variabel respon). 


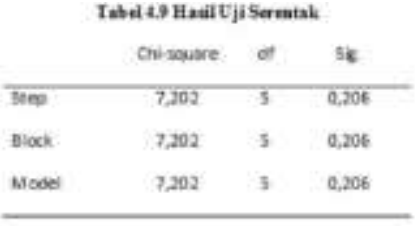

Berdasarkan Tabel 4.9 dapat diketahui nilai $G$ sebesar 7,202 dengan nilai signifikansi sebesar 0,206 (model) $>\alpha=0,05$ berarti Terima $\mathrm{H}_{0}$,

\subsubsection{Uji Kesesuaian Model}

Uji kesesuaian parameter model regresi logistik adalah goodness of fit. digunakan untuk mengetahui keefektifan model dalam menjelaskan variabel dependen.

$\mathrm{H} 0=$ model telah cukup mampu menjelaskan data $\mathrm{H} 1$ = model tidak cukup mampu menjelaskan data

Dari Tabel 4.10 menunjukkan bahwa maka tolak H0. Sehingga pada analisis ini tidak terdapat model yang sesuai dikarenakan variabelvariabel bebas tidak ada yang signifikan.

\begin{tabular}{|c|c|c|c|}
\hline 5 & Giverst & di & $5 x$ \\
\hline 1 & 1111 & 8 & 0,45 \\
\hline
\end{tabular}

Tabel 4.11 Variabel Prediktor Yang Masuk Dalam Uji Serentak

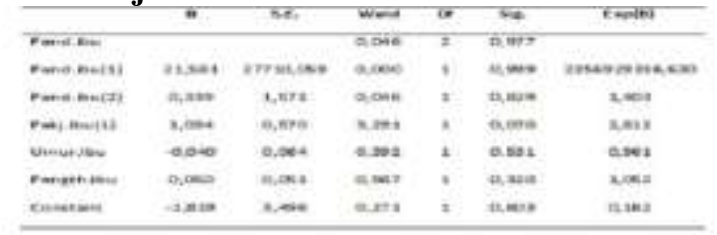

Berdasarkan Tabel 4.11 disimpulkan tidak layak masuk ke dalam model dan tidak dapat dibentuk model logit. Dan untuk pengetahuan ibu tentang imunisasi yaitu sebesar $0,320>$ alpha $(0,05)$ sehingga dapat disimpulkan bahwa pengetahuan ibu tentang imunisasi tidak dapat dimasukkan dalam pemodelan pada analisis regresi logistik biner ini.

\subsubsection{Odds Ratio}

Jika dilihat dari nilai Odds Ratio $(\operatorname{Exp}(\mathrm{B}))$ pada Tabel 4.11 maka dapat disimpulkan yang paling besar kesehatan balita dipengaruhi oleh ibu yang mempunyai pekerjaan adalah 2,812 kali lebih besar daripada variabel yang lain. Dan berdasarkan kecenderungan kesehatan balita berdasarkan pengetahuan ibu tentang imunisasi sebesar 1,052 kali.

Tabel 4.12 Uji Negelkerke

\begin{tabular}{|c|c|c|c|}
\hline $\operatorname{Sop}$ & 2Lof Liefihood & Cos \& Snell R Squate & Sogetikerke R.Square \\
\hline $\mathrm{I}$ & 77,128 & 0,110 & 0,148 \\
\hline
\end{tabular}

Berdasarkan Tabel 4.12 diketahui pengaruh variabel bebas pendidikan ibu, pekerjaan ibu, umur ibu, dan pengetahuan ibu tentang imunisasi terhadap kesehatan balita yaitu sebesar $14,8 \%$ saja. 5.1 Kesimpulan

1. Berdasarkan hasil uji Wald diketahui bahwa variabel bebas (Pendidikan ibu, Pekerjaan ibu, Umur ibu, dan Pengetahuan ibu tentang imunisasi) tidak berpengaruh secara signifikan terhadap variabel terikat (Kesehatan Balita) di Desa Sumput Kecamatan Driyorejo Kabupaten Gresik.

2. Berdasarkan uji Hosmer and Lemeshow mendapatkan hasil $X_{\text {hitung }}^{2}$ sebesar 7,711 dengan signifikansi 0,462. Berarti model regresi logistik biner tidak bisa ditentukan karena data yang dianalisis tidak signifikan.

\subsection{Saran}

Berdasarkan hasil penelitian bahwa variabel bebas (pendidikan ibu, pekerjaan ibu, umur ibu, dan pengetahuan ibu tentang imunisasi) tidak berpengaruh signifikan terhadap kesehatan balita, hal ini berarti selain 4 variabel bebas yang ada masih ada variabel yang lebih berpengaruh terhadap kesehatan balita. Dalam penelitian ini memang pengaruh variabel bebas terhadap varibel terikat sangat sedikit sebesar $14,8 \%$ saja.

Dari kesimpulan diatas meski pengetahuan ibu pengaruhnya cuma sedikit tapi semua ibu harus lebih memperhatikan balita dan mengatur jadwal dari imunisasi itu sendiri untuk pencegahan dari penularan penyakit serta virus yang berbahaya lainnya.

\section{Daftar Pustaka}

DEPKES RI,No.1626/MENKES/SK/XII.2005. pedoman pemantauan dan penanggulangan kejadian ikutan pasca imunisasi, Jakarta.MENKES

Hosmer dan Lemeshow.2000. Applied Logistic Regression.

Https/booksgoogle.co.id.book09.ds/17

Ika Tansil Yulianto,DKK. 2013.Pemodelan Regresi Logistik Ordinal. Studi statistika FMIP Universitas Mulawarman

Jf,Seward.2001. Update on Varicella Kudus Pediat Infect Disj. 2001: 20:619-21

Notoadmojo,Soekidjo.2003.Metodelogi Penelitian Kesehatan. Jakarta . PT Rineka CIpta

Rejeki Hadinegoro,Sri,Sp.Ak. 2014. Buku pedoman imunisasi Indonesia.Ed ke-5. Ikatan dokter anak Indonesia

Rankuti,Freddy 2011. Teknik sampling. Jakarta. PT Gramedia Pustaka Utama halaman 13-15.

Sutrisno Hadi. Teknik sampling. Jakarta. PT Gramedia Pustaka Utama halaman 13-15.

Soekamto,Soejono.2003.Pengantar Ilmu Sosiologi.Jakarta. Erlangga.

Sugiono,2005 Metode Penelitian Administrasi. Bandung . Rineka Cipta 
J Statistika Vol. 10 No. 2, (2017), Hal. 27-34

www.unipasby.ac.id

Ws. Winkel. 1987. Bimbingan Dan Konseling Di Institusi Pendidikan Yogyakarta. Media Abadi 